\title{
O cinema digital como construtor de novos imaginários
}

Eduardo Pires Christofoli

\section{Resumo:}

O presente artigo pretende mostrar algumas ideias sobre como o cinema digital, principalmente em seu processo de pós-produção, pode ajudar na criação de novos imaginários. Em tempos de revolução tecnológica, a entrada dos computadores mudou o processo de realização cinematográfico, permitindo que os cineastas possam criar novos mundos, estes diferentes do nosso. Esta tecnologia produz o irreal, que para o espectador, cada vez mais, passa a se tornar real.

\section{Palavras Chave:}

Cinema digital, imaginário, efeitos visuais.

\begin{abstract}
:
El presente artículo pretende mostrar algunas ideas sobre cómo el cine digital, principalmente en su proceso de posproducción, puede ayudar en la creación de nuevos imaginarios. En tiempos de revolución tecnológica, donde la entrada de las computadoras cambió el proceso de realización cinematográfico, permitiendo que los cineastas puedan crear nuevos mundos, diferentes de lo nuestro. Esta tecnología produce el irreal, que para el espectador, cada vez más, se vuelve real.
\end{abstract}

\section{Keywords:}

Cine digital; imaginario; efectos visuales.

Quando o espectador senta na sala de cinema para assistir a um filme e as luzes se apagam, ele entra em um novo mundo, onde, por duas horas, ele se entregará a uma experiência proposta por um olhar determinado de uma certa realidade.

O cinema trabalha com a questão do imaginário do espectador desde seus primórdios. Foi Georges Méliès quem percebeu, ao assistir as imagens reproduzidas pelo cinematógrafo dos irmãos Lumière, que poderia usar aquela nova tecnologia para contar histórias, começando assim, inconscientemente, a tocar no imaginário do espectador. O cineasta Jean-Luc Godard disse, uma vez, que o grande realista do cinema, no seu início, era Georges Méliès e não os irmãos Lumière, pois ele trabalhava com o imaginário.

Considerando Méliès como o pai dos efeitos especiais e que a partir do conceito dele, tivemos uma evolução tecnológica, passando pelas trucagens e chegando aos efeitos gerados por computador, pode-se concluir que, sem a sua contribuição, o cinema digital de pós-produção não existiria.

Este texto pretende trazer um conceito para o que poderíamos considerar e chamar de imaginário e como o cinema digital, com os seus efeitos e novas possibilidades gerados por computador, vêm provocando 
mudanças neste imaginário.

\section{O imaginário}

O cinema continua vivo por causa da experiência que ele causa no espectador. Ela começa a partir do momento em que uma pessoa conta a outra o filme que viu. Existe neste ato, uma troca de uma experiência, que foi absorvida e repassada adiante, seja bom ou ruim.

O cinema, seja ele ficcional ou documental, se propõe a narrar uma história. Representar um fato real, ou baseado na realidade. Bazin já colocava que o cinema só se concretiza se é baseado na realidade.

Pela sala de cinema possuir um ambiente escuro e nela serem projetadas imagens, sendo a nossa atenção focada nelas, podemos considerar a relação da experiência provocada na sala de cinema com o sonho.

O estado fílmico e o estado onírico tendem a juntar-se quando o espectador começa a adormecer (embora a linguagem corrente, neste grau, não fale de $<>$ ), ou quando o sonhador começa a despertar. Mas a situação dominante é aquela em que o filme e o sonho não se confundem: é que o espectador do filme é um homem acordado, ao passo que o sonhador é um homem que dorme (Metz, 1980: 112).

O autor acima citado fala também sobre um estado de vigília que o espectador chega ao assistir um filme na sala de cinema. Por isso, existem críticos fervorosos que dizem que a sala de cinema não vai desaparecer. A ambiência da sala favorece a este estado e reproduzi-la em outro ambiente é possível, porém mais complicado.

Por achar que não existem filmes que não são narrativos o autor faz a comparação com o mundo dos sonhos, este que compõe narrativas dispersas e cheias de significados que exploram a nossa imaginação, com o mundo construído como uma projeção. Tanto o cinema quanto o sonho tocam no imaginário do espectador, consolidando-se na passagem de compartilhamento deste com outro ser. Levando em conta que, em muitos casos, não conseguimos lembrar alguns fatos que sonhamos, as duas experiências são similares, pois não podemos agarrá-las fisicamente.

É na sala de cinema que acontece a aproximação que atingimos no sonho, este quando estamos dormindo. O sonho se torna uma narrativa quando é contado a outro receptor, mas este irá criar outro imaginário do fato contado. Mas a questão vai além da simples comparação. O que faz o filme ser bom?

[...] os filmes, tal como já o dizem as fórmulas correntes e enigmáticas que se empregam depois de se terem visto, são coisas de que se $<>$ ou de que $<>$ [...] Para que um sujeito $<>$ de um filme, é necessário, em suma que os por menores da diegese lisonjeiem suficientemente os seus fantasmas conscientes e inconscientes a fim de lhe permitir um certo saciamento pucionale é também necessário que este saciamento fique contido dentro de certos limites, que fique para cá do ponto que mobilizariam a angústia e a rejeição. [...] Em fim, todas às vezes em que não se gostou de um filme de ficção é porque ele foi demasiado, ou não o suficiente, ou ambas as coisas (METZ, 1980: 114-115)

A questão do bom ou ruim, do gosto ou não gosto, do prazer e do desprazer é outro problema. Mesmo no desprazer, o filme mexe com o espectador de alguma maneira, fazendo discursar sobre o que não gostou.

Se cada espectador formar sua opinião sobre um filme, criando assim uma imagem, para que esta desperte 
o seu imaginário, pode-se concluir que a imagem é universal, mas sempre particularizada.

No mundo do imaginário tem que ter um fundo do mundo real, logo um filme seria imaginário, pois é nele que temos uma experiência real (presente, no momento em que estamos a assistir o filme), mas só se irá discutí-lo na sua ausência (após o término da sessão). Wolgang Iser, ao analisar a obra de Sartre comenta:

$\mathrm{O}$ ato imaginante é o inverso do ato realizante, é pela maneira com qual apreendo o dado que eu coloco com real aquilo que não é dado. $\mathrm{O}$ ato imaginativo é simultaneamente constitutivo (constitui um objeto irreal), isolador (cria seu próprio "mundo") e aniquilador (deixa de lado as características essenciais do objeto real) (ISER, 1996: 239).

Podemos concluir, então, que ao analisarmos um filme, depois de assisti-lo (seja uma ou várias vezes) passamos a reconstruir as histórias propostas por ele, imaginando e criando até novas versões, pois dados da história nos escapam. Passamos esta experiência para alguém, esta que criará novas imagens para o que está sendo contato. Baseado em algo concreto (o filme), a outra pessoa cria o ato imaginante, criando assim um objeto irreal, pois este está apenas em sua cabeça. Para Iser "O ato imaginante é um ato mágico". Fazendo um objeto irreal aparecer e ser criado pela nossa consciência. A essas ordens da consciência os objetos obedecem: aparecem. O imaginário para Sartre é o que o é a consciência para Freud.

$\mathrm{O}$ ato de imaginação, como acabamos de ver, é um ato mágico. É um encantamento destinado a fazer aparecer o objeto no qual pensamos, a coisa que desejamos, de modo dela possamos tomar posse. [...] Quanto ao resto, o objeto é irreal. Sem dúvida, está presente, mas, ao mesmo tempo, está fora de alcance. Não posso tocá-lo, não posso mudá-lo de lugar - ou melhor, posso sim, mas com a condição de fazê-lo irrealmente, de renunciar a servir-me de minhas próprias mãos, para recorrer a mãos fantasmas (SARTRE, 1996: 165-166).

Podemos tirar deste trecho da análise de Sartre sobre o objeto imaginário, a relação que o espectador tem com o filme que assiste na tela. Ele pode vê-lo, tentar tocá-lo, mas só poderá fazê-lo se abrir mão de sua condição real e embarcar em um estado de vigília, por isso a relação de Metz com o sonho.

O cinema é a junção de todas as artes e está em constante movimento de transformação. Nos seus primórdios, evoluiu de filmes mudos para sonoros, de preto e branco para coloridos, de registros teatrais para realistas.

No cinema, a palavra não tem a missão de aduzir idéias às imagens e nem a música, sentimentos. O todo nos comunica qualquer coisa bem determinada, não se tratando de um pensamento, nem de uma evocação dos sentimentos da vida. [...] Porém, isso não implica estar o filme destinado a nos fazer ver e ouvir que veríamos e ouviríamos caso assistíssemos de verdade à história que ele nos conta (PONTY, 2003: 115).

Logo o espectador sabe que aquilo que ele está vendo não é real, mas o aceita para poder entender o que está acontecendo com aquela história que está sendo contada. Pode-se ver que o espectador forma uma imagem daquilo que vê. Criando um significado, que é o que entendemos, e um significante, que é da ordem do imaginário. Uma questão de causa e efeito, mas o homem não é um animal e não existe uma fórmula para analisar. A imagem não pode ser explicada pelas novas tecnologias, mas estas podem criar novas imagens, alterando os imaginários. 


\section{O cinema digital e as novas tecnologias}

Há alguns anos começamos a ouvir falar do surgimento de tecnologias digitais para aquisição de imagens cinematográficas. Porém, somente há alguns anos atrás tornou-se rotina depararmo-nos com algumas destas tecnologias. A tecnologia digital já não é mais novidade no cinema. Efeitos especiais gerados por computador, edição não-linear e som digital já fazem parte do vocabulário cinematográfico há um bom tempo. Atualmente, diversos modelos de câmeras já estão no mercado e outros tantos ainda estão em testes nas bancadas dos laboratórios.

Chamados primeiramente de trucagens, que consistem segundo Aumont (2003: 95) em "toda manipulação de um filme que acaba mostrando na tela alguma coisa que não existiu na realidade" e depois de efeitos especiais "locução [que] designa os efeitos necessários para produção de imagens não realistas, que não se podem obter pela simples reprodução de uma cena que se desenrola diante da câmera" (AUMONT, 2003). Estes efeitos se aperfeiçoaram ao longo do tempo, tornando-se bem mais sofisticados com a utilização da informática.

Aqui, iremos nos reter no que os efeitos gerados por computadores podem trazer de novo para o imaginário do espectador. No cinema, hoje, tudo é possível. O homem pode voar, parar no ar, visitar o futuro ou o passado, transformar-se em outro ser, disparar rajadas de energia elétrica, seres com feições humanas podem ser extremamente realistas. Tudo isso passou a ser possível com a entrada dos efeitos visuais produzidos por computadores, ou CG, abreviação de Computer Graphics, termo que pode-se traduzir em computação gráfica.

É interessante de analisar como a utilização destas tecnologias, que atingem o seu ápice com o cinema digital, pode mudar a narrativa cinematográfica. Criam-se novos mundos, enquadramentos não possíveis pela câmera real. Sim, agora já existe uma câmera irreal, tomadas inteiras geradas por computador. O diretor Zack Snider, responsável pela direção o filme 300 (2006) comenta algo interessante sobre o processo de realização do filme, filmado todo em fundo azul, tendo os cenários sido construídos por computador.

A tecnologia de computação gráfica avançou muito desde então e em determinado momento dissemos "pro inferno com isso, vamos de tela azul" . E aí fizemos aquele teste que mostramos para a Warner Bros. [...] A idéia ali foi mostrar a ação como os espartanos a viam. A acelerada é como se vista de fora, a em câmera lenta, como os espartanos a percebiam. E também porque o resultado é bacana demais (SNIDER, 2007).

Podemos ver que o que preocupava a cabeça do diretor era sim o resultado estético de sua obra e não o realismo que ela poderia provocar. $\mathrm{O}$ filme provoca sensações diferentes, pois possui uma estética muita parecida com jogos de videogames. Snider (2007) ainda ressalta que:

Eu amo filmes então estou sempre buscando formas de fazer com que as pessoas deixem suas enormes TVs digitais em casa e vão até o cinema para ter uma experiência cinematográfica de verdade. O que tem no cinema que não dá pra ter em casa? A resposta é algo como 300, que é um filme, claro, mas também uma experiência.

Podemos fazer aqui um paralelo com o que colocamos acima (a experiência provocada apenas na sala de cinema). Com as luzes apagadas e tendo a sua atenção voltada apenas para a projeção luminosa a sua frente é fácil o espectador adormecer (usando o termo de Metz) vivendo uma experiência única.

O cinema digital ajuda os filmes a aumentarem essa experiência introduzindo o que poderíamos chamar 
de objetos irreais digitais. Personagens, lugares e ações que não existem no mundo real, ou existem, mas não foram colocados durante as filmagens. Estes por sua vez são tratados como reais no momento em que fazem parte da história contada. Kant já dizia que na arte a inteligência trabalha para a imaginação.

As tecnologias digitais trabalham forçando a inteligência do espectador para fazê-lo acreditar que o que ele está vendo é real e totalmente possível, dentro daquele universo. Iser (1996: 172) coloca que "a duração do objeto enquanto imagem é o correlativo transcendente de um ato posicional especial e, por conseqüência, participa da irrealidade do objeto".

Podemos ver que para que ele possa existir como objeto, o filme deve existir como narrativa, pois esta já possui seus significados e significantes. Servindo os objetos irreais digitais, como complementos sensoriais para percebemos melhor a experiência proposta. Estes objetos podem ser divididos em duas categorias: perceptíveis e não-perceptíveis. Os da primeira categoria seriam aqueles que sabemos que o homem não é capaz de realizar, como voar sem a ajuda de máquinas, poderes mágicos, ou transformações em animais ou coisas. Já os da segunda categoria seriam aqueles que existem no mundo real, mas por serem perigosos ou difíceis de manejar, são aplicados pelo computador, como fogo, chuva, sangue e pequenos objetos (aqui ressalta-se a cena do filme Blindness, com direção de Fernando Meirelles (2008), no qual foi criado digitalmente um pequeno fósforo).

Antes o cinema utilizava-se apenas de sua própria linguagem para poder mexer com o imaginário. Com a criação da montagem, linguagem exclusiva do cinema, começou a manipulação dos acontecimentos da história, podendo sugerir coisas ao invés de mostrá-las. As novas tecnologias vêm com o objetivo de mostrar o irreal, aquilo que não existe fora do filme. Aquilo que nos romances está apenas descrito e aberto para a nossa imaginação. A professora Ana Beatriz Rahde reforça este conceito, fazendo um paralelo interessante com a obra de Méliès.

Na modernidade, Méliès contou e recontou cenas fantásticas, com a manipulação de fotografias animadas dos seus filmes. Esse cineasta desenvolveu inovações e trucagens - princípio dos atuais efeitos especiais -, conferindo grande enriquecimento à linguagem cinematográfica, e assim o cinema foi e tem sido o receptáculo e, ao mesmo tempo, o comunicador do imaginário. As alusões de Méliès aos fantasmas transparentes, à miniaturização de personagens, aos seus roteiros, que apelavam para a fantasia, transformaram o imaginário do espectador num universo simbólico de imagens mentais, afetivas ou mito-mágicas. Hoje o cinema vem retomando contos semelhantes, utilizando, porém, os recursos gráficos/digitais, com maiores possibilidades das técnicas visuais (RAHDE, 2008: 101-102).

É interessante notar como os cineastas contemporâneos têm explorado esta questão: usando hoje as tecnologias digitais para obter estéticas variadas, explorando a questão do cinema como fábrica de sonhos, ou o nosso imaginário. Isso leva o espectador a saber que está sendo enganado, mas ele torna aquilo tão real que passa a acreditar no que está vendo.

Tendo a preocupação com a verossimilhança, o cinema contemporâneo cada vez mais se preocupa em criar heróis e situações verossímeis, utilizando-se das tecnologias digitais para maiores possibilidades das técnicas visuais. Dizem que o efeito visual bom é aquele que ninguém percebe. Pra dar certo, ele precisa fazer parte do contexto, mas não ser o tema principal da história.

Da ficção à realidade, o contemporâneo tecnológico e o imaginário do pós-moderno vêm proporcionando aproximações e novas visões estéticas em transição. O que é o real e o que é o digital? As tecnologias estão comprovando o que era apenas ficção, literatura, arte cinematográfica, imaginário, em um novo mundo de reflexões sobre o impossível, palavra que aos 
poucos estará riscada, pela união da ciência com a imaginação (RAHDE, 2008: 104).

Se puder dizer que o cinema digital é o futuro do cinema como anunciam cineastas como Robert Zemeckis, onde os filmes serão gerados inteiramente por computadores (na chamada técnica Motion Capture ), talvez possamos estar nos enganando. Não podemos negar que ele é o presente e que o cinema o tem usado para dar vida aos imaginários dos realizadores, cada vez buscando ir além do que podemos imaginar.

\section{Conclusão}

O cinema não é arte, o cinema é um mistério. Uma junção da técnica e da arte. É interessante notar que a imagem não pode ser explicada, nem pelas novas tecnologias. Ela vai além da representação, é o que não está colocado na composição. Cada um tem a sua imagem. Então, podemos definir o imaginário?

No sentido corrente, o imaginário é o campo (e o produto) da imaginação, entendida como faculdade criativa. A palavra, praticamente, é empregada como sinônimo de "Fictício", "inventado" e oposta a real. Nesse sentido a diegese de uma obra de ficção é um mundo imaginário. A palavra ganhou um sentido mais técnico na teoria lacaniana que inspirou, por muito tempo, a reflexão sobre o dispositivo cinematográfico. [...] Dessa forma o imaginário designa, portanto, a instância que define e regula a relação metapsicilógica do espectador com o dispositivo (AUMONT, 2003: 164-165).

O imaginário, por poder ser comparado ao sonho, pois cria objetos irreais, objetos que não poderiam existir no mundo dito como real. As tecnologias digitais ajudam os cineastas a chegar perto deste conceito, porque por meio delas, os diretores podem criar o que antes só existia em suas imaginações.

Com os chamados objetos irreais digitais, os realizadores são capazes de criar o que era antes impossível. Aquilo que não poderia ser feito pelas técnicas tradicionais, agora é possível com a inserção dos computadores.

Os efeitos visuais ajudam a criar um paraíso de sonhos, tornando o cinema um realizador de fantasias, encabeçadas pela visão do diretor, responsável por dar a métrica do filme, seu ritmo para que quem o assista possa perceber partes de um todo. O espectador sabe disso e deixa-se levar, ou não, durante a exibição do filme.

O cinema digital vem agregar ao cinema, aumentando as possibilidades de criação. Se a imagem é algo individual e particularizada, o cinema digital lhe dá o infinito como limite. Dando asas à imaginação, para poder criar o inalcançável, o irreal, mas sempre com a preocupação do verossímil.

Se a partir dos efeitos visuais gerados por computador pode-se criar estes objetos irreais digitais, podemos dizer que o cinema digital encontra outra função, além da tradicional e já exaustivamente discutida facilitação e acessibilidade do cinema a todos. Ele pode criar, ou melhor, ampliar as possibilidades de criação. Levar a magia do cinema ao seu extremo.

Se as idéias de um filme partem de mentes criativas, sejam elas de diretores, ou roteiristas, estas que se baseiam em seus imaginários individuais, poderão atingir seu ápice com as novas tecnologias. Se hoje assistimos a filmes que nos impressionam com a sua busca pela verossimilhança, o que poderá nos reservar o amanhã? O limite entre real e imaginário cada vez mais é quebrado, já que não sabemos mais diferenciar se estamos diante de objetos reais, ou objetos irreais digitais. 
Não existe mais limite para a criação cinematográfica. O que vai existir é o bom senso de capturar o essencial, dosando o que deve ou não fazer parte da história que pretende ser contada.

\section{Bibliografia:}

AUMONT, Jacques. A Imagem. Campinas: Papirus, 1993.

AUMONT, Jacques e MARIE, Michel. Dicionário teórico e crítico de cinema. Campinas: Papirus, 2003.

HARRIS, Tom. Como funciona o cinema digital. Disponível em: . Acesso em: 14/06/09.

BERNARDET, Jean-Claude. O que é cinema. 3. ed. São Paulo: Brasiliense, 2000.

GERBASE, Carlos. Impactos das tecnologias digitais na narrativa cinematográfica. Porto Alegre: EDIPUCRS, 2003.

ISER, Wolfgang. O fictício e o imaginário: perspectivas de uma antropologia literária. Rio de Janeiro : EDUERJ, 1996.

METZ, Cristian. O significante imaginário: psicanálise e cinema. Lisboa: Horizontes, 1980.

PONTY, Maurice Merleau-. O cinema e a nova psicologia. In: XAVIER, Ismail (Org.). A experiência do cinema. A experiência do cinema: antologia. Rio de Janeiro: Graal, 2003.

RAHDE, Maria Beatriz Furtado. Comunicação e imaginário nos contos do cinema contemporâneo: uma estética em transição. Comunicação e imaginário nos contos do cinema contemporâneo, n. 12, São Paulo, 2008. p. 97-112.

SARTRE, Jean-Paul. O imaginário: psicologia fenomenológica da imaginação. São Paulo: Ática, 1996.

SNYDER, Zack. Exclusivo - Omelete Entrevista Zack Snyder, o diretor de 300. Disponível em: < http://www.omelete.com.br/cine/100004724.aspx>. Acesso em: 22/06/09.

\section{Notas:}

A edição não linear é quando o filme é convertido para um formato digital e pode ser modificado livremente. Normalmente os filmes são digitalizados no formato AVI, ou MOVIE. Este é um formato bruto, também chamado de Raw, que ocupa muito espaço por minuto de filme. Depois da edição o filme é convertido para algum formato comprimido para ser colocado em fita, película ou DVD, de acordo com a finalidade.

O diretor se refere ao uso de locações reais para rodar o filme.

Motion capture, motion tracking, ou mocap são termos utilizados para descrever o processo de gravação de circulação e traduzir esse movimento para um modelo digital. Inicialmente inventado na Escócia, que é utilizado pelas Forças Armadas, entretenimento, esportes e aplicações médicas. No cinema se refere ao registro de ações humanas para utilização de animação de modelos digitais de personagem em animação $3 \mathrm{D}$. 


\section{Mini Currículo :}

Eduardo Pires Christofoli é mestrando do Programa de Pós-Graduação em Comunicação Social da PUCRS, Graduado no Curso de Produção Audiovisual - Cinema e Vídeo da PUC-RS, Produtor audiovisual, sócio-diretor da Produtora Colateral Filmes. 